\title{
Pengaruh Bauran Pemasaran Terhadap Keputusan Pembelian Pengguna Internet Di Kota Pekanbaru
}

\author{
SRI MULYANA \\ Sekolah Tinggi Ilmu Ekonomi Persada Bunda \\ Jl. Diponegoro No. 42 Pekanbaru \\ E-mail : srimulyana_ewa@ymail.com
}

\begin{abstract}
This study aims to find out the effects of the marketing mix consisting of product, price, promotion, place, both simultaneously and partially, on the consumers' purchase decision to users internet in Pekanbaru. This research used quantitative method. Total sample in this research are 100 costumers, The data were collected by a questionnaire. The results of the data analysis show that: (1) Product have positive and significant effects on the buying decisions tousers internet in Pekanbaru (2) price,place and promotion do not thave positive and significant effects on the buying decisions tousers internet in Pekanbaru 3) Marketing mix together have an influence positive and significant effects on the purchase decisions s tousers internet in Pekanbaru
\end{abstract}

Keywords: marketing mix, purchase decision

Gaya hidup masyarakat saat ini telah berubah kearah Digital Lifestyle. Jika dibangdingkan saat sepuluh tahun kebelakang, masyarakat sekarang ini dalam menggunakan data internet sangat tinggi. Masyarakat saat ini tidak hanya menggunakan alat komunikasi (handphone) untuk menelepon atau mengirim pesan (SMS) saja, tetapi juga memiliki kebutuhan lainnya seperti mencari informasi, e-mail, pembelian/penjualan onlines, treaming, browsing, media sosial. Hal tersebut menjadi kebutuhan masyarakat khususnya pengguna internet dalam keputusan pembelian data internet.

Pekanbaru merupakan salah satu kota pengguna internet yang cukup besar, dikarenakan kebutuhan akan data internet menjadi kebutuhan yang penting dalam kehidupan sehari-hari. Persentase Pengguna internet di Kota pekanbaru dalam mendapatkan informasi/berita, media sosial dan email mengalami kenaikan tiap tahunnya.

Pengguna internet tentunya memilih ataupun menggunakan paket data internet yang dapat diperoleh dari operator seluler yang ada di Kota pekanbaru diantaranya Telkomsel, Indosat maupun XL. Keunggulan masing-masing produk khususnya data internet pada masingmasing operator seluler membuat pengguna internet membeli data internet tersebut sesuai dengan keinginan dan kebutuhan, misalnya dari segi kualitas produknya, kecepatan akses internetnya, kemudahan pengguna internet untuk membeli data internet yang tersebar sampai sudut kota, dan informasiinformasi mengenai keunggulan ataupun promosi yang diberikan dari produk tersebut. Untuk mengamati hal tersebut dapat dilihat bagaimana variabel-variabel dalam bauran pemasaran memiliki pengaruh pada pengguna internet untuk memutuskan membeli data internet di Kota Pekanabru. Untuk itu dapat diketahui bagaimana pengaruh bauran pemasaran (produk, tempat, harga, promosi) terhadap keputusan pembelian pengguna internet di Kota Pekanbaru.

Pemasaran merupakan bagian penting dalam perusahaan dalam pengembangan dan keberlangsungan hidup perusahaan. Pelaksanaan kegiatan pemasaran tidaklah hal yang mudah untuk dilakukan, seluruh karyawan perusahaan harus berperan aktif dalam mencapai tujuan perusahaan. Penjualan barang dan jasa tergantung pada beberapa faktor 
antara lain: kualitas dan penampilan produk perusahaan, cara penyampaian produk dari produsen hingga sampai ke tangan konsumen, dan juga harga yang diterapkan perusahaan.

Menurut Zeithaml dan Bitner (2008:48) menyebutkan bahwa bauran pemasaran (marketing mix) adalah elemenelemen organisasi perusahaan yang dapatdikontrol oleh perusahaan dalam melakukan komunikasi dengan tamu dan untuk memuaskan tamu. Dalam pengertian lain, Alma (2009:243) mengemukakan bahwa marketing mix (bauran pemasaran) adalah strategi mencampur kegiatankegiatan marketing, agar dicari kombinasi maksimal sehingga mendatangkan hasil yang paling memuaskan

Menurut Kotler dan Armstrong (2008:62) "marketing mix is the set of controllable, tactical marketing tools that the firm blends to produce the response it wants in the target market". Marketing mix meliputi item alat pemasaran, yaitu product, price, promotion, dan place (4P). Marketing Mix tersebut digunakan oleh pemasar agar produknya dapat memasuki pasar sasaran atau target market. Item bauran pemasaran meliputi:

a. Product yaitu terdiri dari keragaman produk, kualitas, desain, ciri, nama merk, kemasan, ukuran, pelayanan, garansi (jaminan), dan imbalan.

b. Price yaitu terdiri dari harga, rabat (diskon), potongan harga khusus, periode pembayaran, dan syarat kredit.

c. Promotion yaitu terdiri dari promosi penjualan, periklanan, tenaga penjualan, pubic relation (PR), dan pemasaran langsung.

d. Place yaitu terdiri dari saluran pemasaran, cakupan pasar, pengelompokan, lokasi, persediaan, dan transportasi.

Dari beberapa pengertian di atas dapat disimpulkan bahwa Marketing Mix terdir dari variabel-variabel (product, price, promotion) dalam pemasaran yang dapat dikendalikan dan dipergunakan oleh perusahaan dalam pencapaian sasaran dari tujuan perusahaannya, dan mampu bersaing.

Menurut Sumarni dan Soeprihanto (2010:274) produk adalah setiap apa saja yang bisa ditawarkan di pasar untuk mendapatkan perhatian, permintaan, pemakaian atau konsumsi yang dapat memenuhi keinginan atau kebutuhan". Produk tidak hanya selalu berupa barang tetapi bisa juga berupa jasa ataupun gabungan dari keduanya (barang dan jasa).

Secara konseptual produk adalah pemahaman subyektif dari produsen atas sesuatu yang bias ditawarkan sebagai usaha untuk mencapai tujuan organisasi melalui pemenuhan kebutuhan dan kegiatan konsumen, sesuai dengan kompetensi dan kapasitas organisasi serta daya beli pasar. Selain itu produk dapat pula didefinisikan sebagai persepsi konsumen yang dijabarkan oleh produsen melalui hasil produksinya. Produk dipandang penting oleh konsumen dan dijadikan dasar pengambilan keputusan.

Menurut American Society for Quality Control dalam Lupiyoadi, (2013:213) kualitas adalah keseluruhan ciri-ciri dan karakteristik-karakteristik dari suatu barang atau jasa, dalam hal kemampuan untuk memenuhi kebutuhankebutuhan yang telah ditentukan atau bersifat laten.

Menurut Kotler dan Armstrong (2012;76), promosi adalah "Promotion means activities that communicate the merits of the product and persuade target customers to buy it"artinya promosi merupakan kegiatan yang mengomunikasikan manfaat dari sebuah produk dan membujuk target konsumen untuk membeli produk tersebut.

Menurut Rangkuti (2010;50) promosi kegiatan penjualan dan pemasaran dalam rangka menginformasikan dan mendorong permintaan terhadap produk, jasa, dan ide dari perusahaan dengan cara memengaruhi konsumen agar mau membeli 
Harga menurut Kotler dan Amstrong (2008: 345) adalah sejumlah uang yang ditagihkan atas suatu produk dan jasa atau jumlah dari nilai yang ditukarkan para pelanggan untuk memperoleh manfaat dari memiliki atau menggunakan suatu produk atau jasa.

Harga merupakan sejumlah nilai yang konsumen tukarkan untuk sejumlah manfaat dengan memiliki atau menggunakan suatu barang atau jasa. Harga merupakan hal yang diperhatikan konsumen saat melakukan pembelian. Sebagian konsumen bahkan mengidentifikasikan harga dengan nilai.

Menurut Kotler \& Keller (2009: 184), tempat adalah lokasi yang digunakan untuk proses penyampaian barang dan jasa dari produsen ke konsumen. Variabel tempat mencakup lokasi yang strategis, akses ke lokasi yang mudah dijangkau, penempatan layout produk yang rapi dan teratur, keluasan areal dan kenyamanan suasana belanja, dan keluasan areal dan keamanan parkir kendaraan

Lokasi adalah tempat dimana sesuatu berada. Menurut (Lupiyoadi 2009:42) lokasi merupakan keputusan yang dibuat perusahaan berkaitan dengan dimana operasi dan stafnya akan ditempatkan, dan lokasi merupakan gabungan antara lokasi dan keputusan atas saluran distribusi, dalam hal ini berhubungan dengan cara penyampaian produk kepada konsumen dan dimana lokasi yang strategi.

Menurut Peter dan Olson dalam Sangadji (2013:332) keputusan pembelian adalah proses pemecahan masalah yang diarahkan pada sasaran. Menurut Supranto dan Nandan (2011:12) proses keputusan konsumen merupakan intervensi antara strategi pasar. Ini artinya, hasil (outcomes) dari strategi pemasaran perusahaan ditentukan oleh interaksinya dengan proses keputusan konsumen.

Menurut Setiadi dalam Fahmi (2016:57) mendefinisikan bahwa inti dari pengambilan keputusan konsumen adalah proses pengintegrasian yang mengkombinasikan pengetahuan untuk mengevaluasi dua perilaku alternatif atau lebih, dan memilih salah satu di antaranya. Hasil dari proses pengintergrasian ini adalah suatu pilihan yang disajikan secara kognitif sebagai keinginan berperilaku.

Menurut Engel et al dalam Sangadji (2013:334) mengemukakan 5 tahapan perilaku konsumen dalam pengambilan keputusan pembelian, yaitu :

1. Pengenalan kebutuhan

Pengenalan kebutuhan muncul ketika konsumen menghadapi suatu masalah, ketika dalam keadaan di mana terdapat perbedaan antara keadaan yang diinginkan dengan yang terjadi.

\section{Pencarian informasi}

Konsumen akan mencari informasi yang tersimpan dalam ingatannya (pencarian internal) dan mencari informasi dari luar (pencarian eksternal).

3. Evaluasi alternatif

Konsumen membandingkan berbagai merek pilihan yang dapat memberikan manfaat kepadanya serta masalah yang dihadapinya.

4. Keputusan pembelian

Pembeli akan menentukan sikap dalam pengambilan keputusan apakah membeli atau tidak.

5. Hasil

Tahap di mana konsumen akan merasa puas atau tidak dan ini akan memberikan informasi pada pelaku usaha bisnis apakah produk atau layanan yang telah dijual dapat memuaskan konsumen atau tidak.

Menurut Fahmi (2016:62) adapun tahap - tahap pengambilan keputusan pembelian adalah : 1 . Mendefinisikan

masalah tersebut secara jelas dan gamblang, atau mudah untuk dimengerti. 2. Membuat daftar masalah yang akan dimunculkan, dan menyusunnya secara prioritas dengan maksud agar adanya sistematika yang lebih terarah dan terkendali. 3. Melakukan identifikasi dari setiap masalah tersebut dengan tujuan untuk lebih memberikan gambaran secara lebih tajam dan terarah secara lebih 
spesifik. 4. Memetakan setiap masalah tersebut berdasarkan kelompoknya masing - masing yang kemudian selanjutnya dibarengi dengan menggunakan model atau alat uji yang akan dipakai. 5 . Memastikan kembali bahwa alat uji yang dipergunakan tersebut telah sesuai dengan prinsip-prinsip dan kaidah-kaidah yang berlaku pada umumnya.

Menurut Suryani (2008:13) keputusan pembelian barang atau jasa sering sekali melibatkan dua pihak atau lebih. Umumnya ada 5 peranan yang terlibat, meliputi : 1. Pemrakarsa

(initiator), yaitu orang yang pertama kali menyarankan ide untuk membeli suatu barang/jasa. 2. Pembawa pengaruh (influencer) yaitu orang yang memiliki pandangan atau nasihat yang mempengaruhi keputusan pembelian. 3.

Pengambilan keputusan (decider), yaitu orang yang menentukan keputusan pembelian. 4. Pembeli (buyer), yaitu orang yang melakukan pembelian secara nyata. 5 .

Pemakai (user), yaitu orang yang mengkonsumsi dan menggunakan barang/jasa yang dibeli.

Keputusan pembeli yang dilakukan konsumen, dipengaruhi banyak hal (Manap, 2016:242), yaitu :

1. Faktor Kebudayaan

Kebudayaan sangat berpengaruh terhadap nilai-nilai dan pola perilaku konsumen anggota kebudayaan tertentu.

2. Faktor Kelas Sosial

Orang-orang dalam kelas sosial tertentu cenderung memiliki perilaku, kebiasaan tertentu dalam kehidupan seharihari, termasuk dalam menentukan produk apa yang akan dikonsumsi.

\section{Faktor Keluarga}

Banyak sedikitnya jumlah barang yang dikonsumsi dan mutu barang yang dipilih antara keluarga kecil dan keluarga besar sangatlah berbeda.

4. Faktor Refensi Group (kelompok)

Pola pikir seorang individu dalam mengambil keputusan untuk membeli suatu produk dapat dipengaruhi oleh masukan, arahan, pemikiran dan sebagainya dari sesama anggota kelompok.

Menurut Kotler dalam Priansa (2017:89) indikator keputusan pembelian terdiri dari pilihan produk, pilihan merek, pilihan saluran pembelian, waktu pembelian dan jumlah pembelian

\section{METODE}

Penelitian ini menggunakan metode kuantitatif,Adapun yang menjadi populasi dalam penelitian ini adalah seluruh penduduk Pekanbaru tahun 2017 yaitu 1.046.566 jiwa. . Bila populasi besar, dan penelitian tidak mungkin mempelajari semua yang ada pada populasi, misalnya karena keterbatasan dana, tenaga dan waktu, maka peneliti dapat menggunakan sampel yang diambil dari populasi itu. Rumus yang dipakai untuk mengetahui jumlah sampel adalah menggunakan rumus slovin, yaitu:

$\mathrm{n}=\mathrm{N} /\left(1+\mathrm{N \alpha}^{2}\right)$

Keterangan :

$\mathrm{n}=$ Ukuran sampel

$\mathrm{N}=$ Ukuran Populasi

$\alpha=$ Toleransi ketidaktelitian (10\%)

Berdasarkan rumus, maka

$\mathrm{n}=\frac{1}{1}=99,99=100$

$1+1.046 .566(0,1)^{2}$

Berdasarkan perhitungan di atas maka di dapat jumlah sampel adalah 100 . Adapun teknik pengambilan sampel dalam penelitian ini dengan menggunakan simple random sampling

Metode yang digunakan peneliti untuk menganalisa data dalam penelitian ini yaitu menggunakan metode regresi linear berganda. Berikut model persamaan regresi linier berganda adalah sebagai berikut :

$\mathrm{Y}=\mathrm{a}+\mathrm{b}_{1} \mathrm{X}_{1}+\mathrm{b}_{2} \mathrm{X}_{2}+\mathrm{b}_{3} \mathrm{X}_{3}+\mathrm{b}_{4} \mathrm{X}_{4}$

Keterangan :

$\begin{array}{ll}\mathrm{Y} & =\text { Keputusan Pembelian } \\ \mathrm{X}_{1} & =\text { Produk } \\ \mathrm{X}_{2} & =\text { Harga } \\ \mathrm{X}_{3} & =\text { Promosi } \\ \mathrm{X}_{4} & =\text { Tempat } \\ \mathrm{a} & =\text { konstanta } \\ \mathrm{b} 1-4 & =\text { koefisien regresi }\end{array}$




\section{Uji t}

Uji statistik $t$ pada dasarnya menunjukkan seberapa jauh pengaruh satu variabel penjelas/independen secara individual dalam menerangkan variasi variabel dependen (Ghozali, 2009:84). Sedangkan menurut Priyono (2009:149) uji ini dapat dilakukan dengan membandingkan $t$ hitung dengan $t$ tabel atau dengan melihat kolom signifikansi pada masing-masing $t$ hitung. Adapun kriteria pengambilan keputusan yang digunakan dalam pengujian ini adalah sebagai berikut:

a. Apabila $t$ hitung $>t$ tabel $/ t$ hitung <$t$ tabel atau Sig $<\alpha$, maka variabel independen berpengaruh signifikan terhadap variabel dependen.

b. Apabila $t$ hitung $\leq t$ tabel $\leq t$ hitungatau Sig $\geq \alpha$, maka variabel independen tidak berpengaruh signifikan terhadap variabel dependen.

\section{Uji Simultan (Uji F)}

Uji simultan $F$ pada dasarnya menunjukkan apakah semua variabel independen atau bebas yang dimasukkan dalam model mempunyai pengaruh secara bersama-sama terhadap variabel dependen. Langkah-langkah penentuannya:

a. Ho: $b 1=b 2=0$ artinya tidak ada pengaruh dari variabel independen terhadap variabel dependen.

b. HA: $b 1 \neq b 2 \neq 0$ artinya ada pengaruh dari variabel independen terhadap variabel dependen.

c. Menentukan kritis (Ftabel)

Dipilih level of significant $=0.05$

Drajat bebas pembilang $(\mathrm{df} 1)=\mathrm{k}$

Drajat bebas membagi $(\mathrm{df} 2)=\mathrm{n}-\mathrm{k}-1$

F kritis $=0.05$ dan df 2 (lihat tabel)

\section{Koefisien Determinasi $\left(\mathbf{R}^{2}\right)$}

Koefisien determinasi pada regresi linear sering diartikan sebagai seberapa besar kemampuan semua variabel bebas dalam menjelaskan varian dari variabel terikatnya.Koefisien determinasi $\left(\mathrm{R}^{2}\right)$ digunakan untuk mengetahui persentase variabel independen secara bersama-sama dapat menjelaskan variabel dependen.Nilai koefisien determinasi adalah di antara nol dan satu. Jika koefisien determinasi $\left(\mathrm{R}^{2}\right)=$ 1 , artinya variabel independen memberikan informasi yang dibutuhkan untuk memprediksi variabel-variabel dependen. Jika koefisien determinasi $\left(\mathrm{R}^{2}\right)=0$, artinya variabel independen tidak mampu menjelaskan pengaruhnya terhadap variabel dependen.

\section{HASIL}

Berdasarkan perhitungan regresi berganda antara variabel Harga (X1), Produk (X2), Place (X3), Promosi (X4), dan Keputusan Pembelian (Y) dengan dibantu program SPSS 20 IBM dalam perhitungannya dapat diperoleh hasil sebagai berikut :

Dari Tabel di atas menunjukan bahwa nilai koefisien regresi variabel bebas dari masing- masing variabel bebas yang mempengaruhi kepuasan pelanggan adalah masing-masing untuk Harga sebesar -,108, Produk sebesar 0,592, Place sebesar -,206, Promosi 0,065, sedangkan nilai parameter konstan (Constante parameter) sebesar 20,630. Berdasarkan nilai tersebut maka estimasi model regresi dapat diformulasikan dalam persamaan regresi berganda seperti berikut ini : $\mathrm{Y}=20,630$ $0,108+0,592-0,206+0,065$ Persamaan diatas dapat dijelaskan sebagai berikut :

a. Nilai 20,630 adalah nilai konstanta yang artinya ketika variabel harga, produk, place,dan promosi dianggap konstan atau tidak ada perubahan maka besarnya variabel Y (keputusan pembeli) adalah sebesar 20,630

b. Nilai koefisien pada variabel Harga (X1) sebesar 0,108 dan bertanda negatif ini menunjukkan bahwa variabel Harga mempunyai pengaruh yang berlawanan arah dengan keputusan pembeli, hal ini mengandung arti bahwa setiap peningkatan (kenaikan) satu satuan maka variabel keputusan pembeliakan turun sebesar 0,108 dengan asumsi bahwa variabel bebas yang lain dari model regesi adalah tetap.

c. Nilai koefisien variabel Produk (X2) 
sebesar 0,592 hal ini menunjukkan bahwa setiap kenaikan variabel Produk satu satuan maka variabel keputusan pembeli(Y) akan naik sebesar 0,592 dengan asusmsi bahwa variabel bebas yang lain dari model regresi adalah tetap.

d. Nilai koefisien pada variabel Place (X3) sebesar 0,206 dan bertanda negatif ini menunjukkan bahwa variabel Place mempunyai pengaruh yang berlawanan arah dengan keputusan pembeli, hal ini mengandung arti bahwa setiap peningkatan (kenaikan) satu satuan maka variabel keputusan pembeli akan turun sebesar 0,206 dengan asumsi bahwa variabel bebas yang lain dari model regesi adalah tetap.

e. Nilai koefisien variabel Promosi (X4) sebesar 0,065 hal ini menunjukkan bahwa setiap kenaikan variabel promosi satu satuan maka variabel keputusan pembeli (Y) akan naik sebesar 0,065 dengan asusmsi bahwa variabel bebas yang lain dari model regresi adalah tetap.

Untuk nilai Koefisien korelasi (R) sebesar 0,422 artinya pengaruh variabelvariabel independen Harga, Produk, Place, Promosi dan Keputusan Pembelian cukup kuat.

Koefisien determinan (Rsquare) sebesar 0,178 dan Koefisien determinan yang disesuaikan adalah sebesar 0,178 karena persamaan regresi menggunakan empat variabel independent. Dari hasil itu terlihat bahwa menunjukan persamaan regresi yang dapat menggambarkan cukup kuat terhadap Keputusan Pembelian.

\section{PEMBAHASAN}

Pengaruh Produk Terhadap Keputusan Pembelian

Dari hasil perhitungan diperoleh nilai t hitung untuk variabel produk adalah sebesar 3,585 dan dengan menggunakan level significance (taraf signifikasi) sebesar 5\% diperoleh $\mathrm{t}$ tabel sebesar 1,980 Di mana $\mathrm{t}$ tabel didapat dari $\mathrm{dk}=\mathrm{n}-\mathrm{k}(100-4-1)=95$ yang berarti bahwa nilai t hitung lebih besar dari t tabel yaitu $3,585<1,980$. Sedangkan nilai sig sebesar 0,001 karena sig lebih kecil dari 0,05 yaitu menunjukan bahwa Produk (X2) mempunyai pengaruh yang positif dan signifikan terhadap Keputusan Pembelian (Y) . Dengan demikian dapat disimpulkan bahwa Ho ditolak dan Ha diterima sehingga hipotesis yang menyatakan Produk mempunyai pengaruh yang positif dan signifikan terhadap Keputusan Pembelian diterima.

Pengaruh Harga Terhadap Keputusan Pembelian

Dari hasil perhitungan diperoleh nilai t hitung untuk variabel Harga adalah sebesar $-0,780$ dan dengan menggunakan level significance (taraf signifikasi) sebesar $5 \%$ diperoleh $\mathrm{t}$ tabel sebesar 1,980 Di mana $\mathrm{t}$ tabel didapat dari $\mathrm{dk}=\mathrm{n}-\mathrm{k}(100-4-1)=95$ yang berarti bahwa nilai t hitung lebih kecil dari t tabel yaitu $-0,780<1,980$. Sedangkan nilai sig sebesar 0,438 karena sig 0,438 lebih besar dari 0,05 yaitu menunjukan bahwa Harga (X1) tdk mempunyai pengaruh yang positif dan signifikan terhadap Keputusan Pembelian (Y) . Dengan demikian dapat disimpulkan bahwa Hoditerima dan $\mathrm{Ha}$ ditolaksehingga hipotesis yang menyatakan Harga tidak mempunyai pengaruh yang positif dan signifikan terhadap Keputusan Pembelian ditolak.

Pengaruh Tempat (Place) Terhadap Keputusan Pembelian

Dari hasil perhitungan diperoleh nilai t hitung untuk variabel Tempat adalah sebesar -1,076 dan dengan menggunakan level signifikansi (taraf signifikasi) sebesar $5 \%$ diperoleh $\mathrm{t}$ tabel sebesar 1,980 Di mana $\mathrm{t}$ tabel didapat dari $\mathrm{dk}=\mathrm{n}-\mathrm{k}(100-4-1)=95$ yang berarti bahwa nilai thitung lebih kecil dari t tabel yaitu $-1,076<1,980$. Sedangkan nilai sig sebesar 0,285 karena sig 0,285 lebih besar dari 0,05 yaitu menunjukan bahwa Place (X3) tdk mempunyai pengaruh yang positif dan signifikan terhadap Keputusan Pembelian (Y) . Dengan demikian dapat disimpulkan bahwa Ho diterima dan Ha ditolak sehingga hipotesis yang menyatakan Tempat tidak mempunyai 
pengaruh yang positif dan signifikan terhadap Keputusan Pembelian ditolak.

Pengaruh Promosi Terhadap Keputusan Pembelian

Dari hasil perhitungan diperoleh nilai $\mathrm{t}$ hitung untuk variabel Promosi adalah sebesar 0,645 dan dengan menggunakan level significance (taraf signifikasi) sebesar $5 \%$ diperoleh $\mathrm{t}$ tabel sebesar 1,980 Di mana $\mathrm{t}$ tabel didapat dari $\mathrm{dk}=\mathrm{n}-\mathrm{k}(100-4-1)=95$ yang berarti bahwa nilai t hitung lebih kecil dari $t$ tabel yaitu $0,645<1,980$. Sedangkan nilai sig sebesar 0,521 karena sig 0,521 lebih besar dari 0,05 yaitu menunjukan bahwa Promosi (X4) tdk mempunyai pengaruh yang positif dan signifikan terhadap Keputusan Pembelian (Y) . Dengan demikian dapat disimpulkan bahwa Hoditerima dan $\mathrm{Ha}$ ditolak sehingga hipotesis yang menyatakan Promosi tidak mempunyai pengaruh yang positif dan signifikan terhadap Keputusan Pembelian ditolak.

Koefesien Determinasi

Untuk mengetahui besarnya pengaruh Produk, Harga,Tempat, Promosi dan Keputusan Pembelian dapat dilihat dari besarnya nilai adjusted $\mathrm{R}^{2}$. Dapat diketahui bahwa besarnya nilai koefisien determinasi ditunjukkan oleh nilai Adjusted R Square yaitu sebesar 0,178 yang artinya bahwa variasi dari semua variabel bebas Harga, Produk, Place, Promosidapat menerangkan variabel Keputusan Pembeliansebesar 17,8\% sisanya sebesar $82,2 \%$ diterangkan dalam variabel lain yang tidak diteliti dalam penelitian ini.

\section{SIMPULAN}

Berdasarkan hasil penelitian dapat disimpulkan bahwa : Produk mempunyai pengaruh yang positif dan signifikan terhadap Keputusan Pembelian pengguna internet di Pekanbaru. Harga, Tempatdan promosi tidak mempunyai pengaruh yang positif dan signifikan terhadap Keputusan Pembelian pengguna internet di Pekanbaru. Bahwa variasi dari semua variabel bebas Harga, Produk, Place, Promosi dapat menerangkan variabel Keputusan Pembelian sebesar $17,8 \%$ sisanya sebesar $82,2 \%$ diterangkan dalam variabel lain yang tidak diteliti dalam penelitian ini.

Dari hasil penelitian, ternyata tidak semua variabel bauran pemasaran berpengaruh signifikan, hal tersebut dapat dilihat bahawa bauran pemasaran tidak seluruhnya berpengaruh terhadap keputusan pembelian pengguna internet dalam membeli paket data internet di kota pekanbaru. Masyarakat Pekanbaru khususnya pengguna internet lebih mengutamakan produk yaitu paket data yang dijual oleh operator seluler. Pengguna internet memilih kualitas dari produk tersebut, baik dari kualitas jaringan yang luas serta kecepatan akses internet yang dapat mempermudah dalam mendapat informasi, kelancaran dalam penggunaan media sosial, belanja online dan lain sebagainya.

\section{DAFTAR RUJUKAN}

Alma, Buchari dan Ratih Hurriyati., 2009.Manajemen Corporate \& Strategi Pemasaran Jasa Pendidikan.

Buchory, Achmad Herry \& Saladin Djaslim. (2010).Manajemen Pemasaran:Edisi Pertama. Linda Karya: Bandung Edisi Pertama., Graha Ilmu., Yogyakarta.

Fahmi, Irham.2016. Perilaku Konsumen Teori dan Aplikasi. Alfabeta.Bandung.

Gary Armstrong. 2012. Prinsip-prinsip Pemasaran. Edisi 13. Jilid 1. Erlangga: Jakarta.

Ghozali, Imam. 2011. “Aplikasi Analisis Multivariate Dengan Program SPSS". Badan Penerbit Universitas Diponegoro: Semarang 
Kotler dan Keller. 2009. Manajemen Pemasaran. Jilid I. Edisi ke 13 Erlangga: Jakarta.

Kotler, Philip dan Keller, Kevin Lane. 2009. Manajemen Pemasaran. Edisi 13.Jilid 1. Jakarta:PT Erlangga

Kotler,Philip dan Amstrong. 2008. PrinsipPrinsip Pemasaran. Jilid 1. Edisi Keduabelas. Jakarta: PT. Indeks.

Lupiyoadi, Rambat \& A. Hamdani. 2009. Manajemen Pemasaran Jasa, Edisi kedua, PT Salemba Empat: Jakarta

Lupiyoad, Rambat.2013. Manajemen Pemasaran Jasa. Edisi 3.Jakarta : Salemba Empat

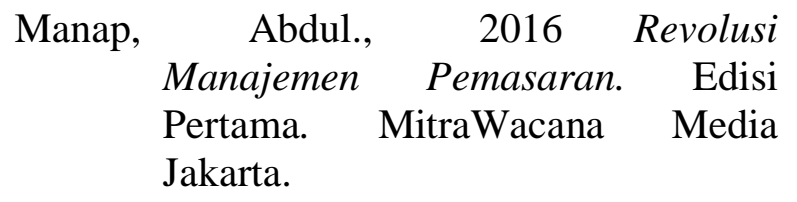

Priansa, Donni. 2017.Perilaku Konsumen dalam Persaingan Bisnis Komputer. Alfabeta. Bandung.

Rangkuti, Freddy. 2010. Analisis SWOT Teknik Membedah Kasus Bisnis. PT Gramedia Pustaka Utama: Jakarta

Sangadji, Sopiah., 2013. Perilaku Konsumen Pendekatan Praktis. Andi Offset. Yogyakarta.

Sugiyono. 2012. Metode Penelitian Kuantitatif Kualitatif dan $R \& D$. Alfabeta : Bandung

Sumarni, Murti dan John Soeprihanto. 2010. Pengantar Bisnis (Dasar-dasar Ekonomi Perusahaan). Edisi ke 5. Yogyakarta: Liberty Yogyakarta

\footnotetext{
Supranto, Nandan Limakrima. 2011. Perilaku Konsumen dan Strategi Pemasaran. Edisi Kedua., Mitra Wacana Media. Jakarta.
}

Suryani, Tatik. 2008. Perilaku Konsumen Implikasi pada Strategi Pemasaran.Edisi Pertama.Graha Ilmu., Yogyakarta.

Valarie A. Zeithaml \& Mary Jo Bitner. 2008. Service Marketing. Jakarta. Global Books Indonesia : The McGraw Hill Companies. 